\title{
At Home with the Hitlers. The Hitlers' Kitchen (Doma u Hitlerů. Hitlerovic kuchyñ)
}

Author: Arnošt Goldflam

First Published: 2007

Theatre Adaptations: Brno, HaDivadlo (2007); Olomouc, Divadlo Tramtarie (2008); Prague, Divadlo Kolowrat (2009); Prague, Divadlo v Dlouhé (2009); Cheb, Západočeské divadlo (2010); Košice, Štátne divadlo (2015).

About the Author: Arnošt Goldflam (1946) comes from a Czech-Austrian-Polish Jewish family, his parents survived the Holocaust. He is known as a playwright, theatre director, actor, novelist writing for children and adults. In 1977, he graduated from Janáček Academy of Music and Performing Arts (Brno). In 2007, Goldflam was appointed professor at the Theatre Academies in Prague and Brno. Jewish topics and the Holocaust occupy an important role in his works. For instance, he adapted several of Franz Kafka's works for theatre (The Metamorphosis, 1989; The Trial, 1989; The Judgment, 1991). He also took part as a screenwriter in two TV documentary films which contained his interviews with Czech, Slovakian and German Jews who had emigrated from Czechoslovakia to Israel, Lost Home (Ztracený domov) and Found Home (Domov nalezený), both 1996.

Further Important Publications: Písek (1986, The Sand; play); Sladký Theresienstadt (1996, $\rightarrow$ Sweet Theresienstadt; play); Smlouva (1999, The Contract; play); Osudy a jejich pán (2005, The Fates and Their Lord; short stories); Standa a dům hrůzy (2008, Standa and a House of Horror; stories for children).

\section{Content and Interpretation}

The play consists of six parts, arranged as loosely tied together separate scenes. As an exposition (Part One), the young Hitler and Stalin happen to meet at the Brno railway station. Hitler is on the way to apply for art studies in Vienna. He declares himself to be an "artist, philosopher and pacifist" (Goldflam, 2007, p. 9). Stalin also changes trains in Brno, on his way to Switzerland because of political affairs. Both travellers find themselves together in a rather excessive conversation about their dreams for the future. The wannabe artist Hitler fantasises about a monumental building, a new "central dominant" for the inhabitants of Brno, to replace the architectonic function of the old Špilberk jail. Both of them outdo each other: Stalin proclaims "houses like heros”, Hitler "houses like Gods”, buildings that people should admire like "old Germanic pyramids" (p. 14). These and other phrases show that Goldflam's piece is best characterised as a farce, combining ridiculous megalomania and self-voiding phrases and actions.

Ә Open Access. () 2021 Wolfgang F. Schwarz, published by De Gruyter. (c) BY-NC-ND This work is licensed under a Creative Commons Attribution-NonCommercial-NoDerivatives 4.0 License. https://doi.org/10.1515/9783110671056-005 
Part Two, entitled Hitler and Gemütlichkeit (cosiness and friendliness) at Home (around 25 Years Later) gives an idea about abysmal banality, brought in with further gobbets of mental nonsense. The bimbo-like Eva Braun naively suggests that Adolf should take her with him on an inspection trip to a pretty place called "Birkenau".

The shifts into the bizarre become more and more intense: When Hitler responds to Eva's bashful wish for a child with his own fantasy about performing the act of conception of their child, the Nazi-environment is expanded to a kitschy monstrosity. As Hitler imagines, the act should be accompanied by music from Wagner and torchbearing SS men. Choirs of the SS and German virgins should sing, generals of the Wehrmacht would have to show up, and after all, the couple should fly away in a Zeppelin. Not to forget that the whole action would have to be filmed by "Leni [Riefenstahl]". (pp. 23-24)

As if this is not enough, in Part Three, A Love Romance, the play is still more enriched with grotesque effects. Hitler sings and dances in his bunker (pp. 25-26). He produces himself as a genius of jokes, giving a parody of himself. As the "Bull of the nations” (p. 29), he also acts in a secret Nazi programme: that day, he is to inseminate a delegation of 88 Czech virgins. The hyperbole results in a gag: instead of the girls, there appears a cow wearing a sash in Czech national colours (blue-white-red) around its neck.

In the fourth part, presented under the cover of An Ordinary Day, the Holocaust theme is touched once more, when Hitler gets a letter from Mengele.

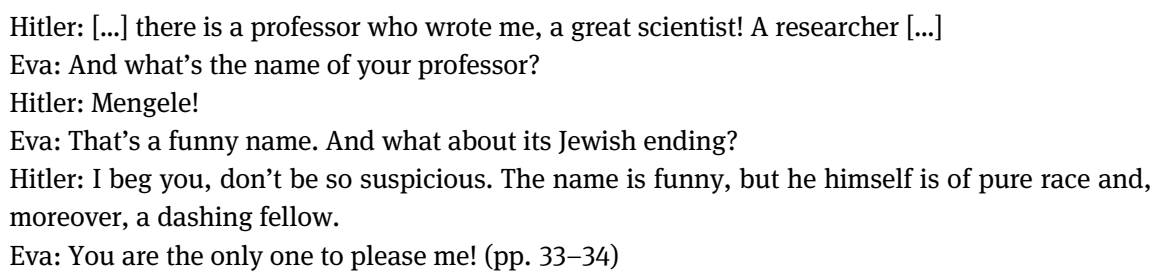

The shift into the bizarre keeps increasing: In the fifth part, called Playing the Game of Death, the villain also nullifies his world physically: He murders his companions Göring, Goebbels and Himmler with poisoned smarties. Dancing Samba with his newly married wife Eva, he seems to be already prepared to escape from Europe.

In Part Six, All's Well That Ends Well, Hitler, now undercover alias “Adolfo Esperanza Muñoz", appears again, during a carnival fiesta in South America, in a bizarre mask (p. 48). Taking the mask off, he presents himself as a people's painter in his new homeland, and distributes smarties among the children. But he falls out of his role as a friendly "uncle Adolpho". When discovering a scorpion, he pitches a violent fit, swearing in German. The theatre gives a satiric lesson in horrible "banality of the evil" (Arendt, 1964, p. 252). The ending can be understood symbolically as a warning against the hidden persistence of this evil. 


\section{Main Topics and Problems}

The play provokes questions about the aesthetic means for critical artistic depictions of the era of the Nazis and its context, e.g. whether "humour and irony" (Firlej, 2016) are apt devices for an adequate treatment of this subject-matter (similar questions also came up concerning George Tabori's approach; discussed by Anat Feinberg, 1999). The character outline of the dramatis personae satirically joins Hannah Arendt's idea formulated in her famous report Eichmann in Jerusalem (1964, p. 252) and shows the banality of the evil characters. The public is challenged to imagine them as dummies of what Arendt called in the full wording of her phrase the "fearsome, word-andthought-defying banality of the evil” (p. 252). Using grotesque (comedy) and farce, Goldflam's poetics of ironic-sarcastic distance to the Hitler figure drives the world of this "genius of mediocrity", of this henpecked family man (Goldflam, Kubičková, 2009), into self-voiding. This basic feature is fostered by various shifts from the serious to the comic and grotesque, from the real to the surreal. See also Grosman's $\rightarrow$ The Shop on Main Street or Pick's $\rightarrow$ Society for the Prevention of Cruelty to Animals. As Agata Firlej (2016, p. 108 and 113) mentions, the roles show affinities to the sketch I, 12 (1969) of Monty Python. Goldflam launches a provoking series of absurd constellations ending up in a mise en abyme which leaves the villains and their entourage as ridiculous and at the same time morally despicable figures. "Banality, mental bullshit disguised as normality and growing into monstrosity [...] is exposed to destroying laughter." (Schwarz, 2014, p. 170)

Goldflam dedicated this piece to the famous Budapest-born theatre maker George Tabori (1914-2007). Tabori is known for his dramatic farce Mein Kampf (1987) "parodying Hitler's rise to power" (Meirich, 2013, p. 60) and for staging the Holocaust, combining Jewish self ironic wit, grotesque humour, sarcasm and tragic situations, e.g. in The Cannibals (1968; more about that in Feinberg, 1999, pp. 34, 257-267). According to Goldflam's dedication in At Home With the Hitlers (Goldflam, 2007, p. 3), Tabori reported that once, when he was a little boy, his father had lost him at the Brno train station. In Part One of Goldflam's play, this motif is implied where Brno serves as a fictitious meeting point on the crossroads of history.

\section{Cited Works}

Arendt, H. (1964). Eichmann in Jerusalem: A Report on the Banality of Evil, 2nd. enlarged ed. New York: Viking Press. Feinberg, A. (1999). Embodied Memory: The Theatre of George Tabori. Iowa City: University of Iowa Press. Firlej, A. (2016). Humour and Irony as Forms of Aestheticization of Shoah Narration: The Play Doma u Hitlerů by Arnošt Goldflam. In R. Ibler, ed., The Holocaust in Central European Literatures and Cultures: Problems of Poetization and Aestheticization. Stuttgart: ibidem, pp. 103-114. Goldflam, A. (2007). Doma u Hitlerů. Hitlerovic kuchyñ. Brno: Větrné mlýny. Goldflam, A., Kubíčková, K. (2009). Arnošt Goldflam představí v Dlouhé průměrného pantátu Hitlera.

iDnes.cz/Kultura, 29. 11. 2009. Available at: https://www.idnes.cz/kultura/divadlo/ arnost-goldflam-predstavi-v-dlouhe-prumerneho-pantatu-hitlera.A091127_221935_div 
adlo_jaz [Accessed: 25.01.2020]. Meirich, H. (2013). A Laughing Matter? The Role of Humor in Holocaust Narrative. Master Degree Thesis. Arizona State University. Available at: https://www.semanticscholar.org/paper/A-Laughing-Matter-The-Role-ofHumor-in-Holocaust-by-Ghanem-Holian/ee001d502bc2bd65bb929069231d04a7c8388 68d [Accessed: 23.01.2020]. Schwarz, W. F. (2014). Holocaust und KZ im Fokus tschechischer Literatur nach 2000. Zu Arnošt Goldflams „Doma u Hitlerů“ und Radka Denemarkovás „Peníze od Hitlera“. In R. Ibler, ed., Der Holocaust in den mitteleuropäischen Literaturen und Kulturen seit 1989. The Holocaust in the Central European Literatures and Cultures since 1989. Stuttgart: ibidem, pp. 157-171.

\section{Further References}

Goldflam, A. (2007). Vážený pane Tabori [...]. Arnošt Goldflam píše Georgu Taborimu. Divadelní noviny, 16 (14), p. 15.

WFS 